\title{
Teachers' Enactment of Equity in Alternative Schools: A critical discourse analysis
}

\author{
Lynn Hemmer \\ Texas A\&M International University \\ Lynn.hemmer@tamiu.edu
}

\begin{abstract}
Purpose: Understanding the needs of at-risk students is thought to be an essential element for educators when they formulate and design alternative educational settings. Yet, it may be difficult for educators to distinguish between responding to the needs of an at-risk student and providing educational equity. The researcher applied equity principles and policy implementation literature to explore how alternative school teachers of at-risk students define, interpret and enact equity. Research Methods: This research was designed as a qualitative cross-case study focusing on five alternative schools in California and Texas. A qualitative thematic analysis was first applied to interviews from fifteen alternative school teachers, followed by a critical discourse analysis of government artifacts, and discursive and social practices. Findings: Teachers' enactment of equity equated to opportunity; at-risk students were afforded equity by virtue of enrollment in the schools. Implicitly, teachers acted as gate keepers to their classroom and as such only certain students were entitled to attend. Equity arguments emerged when external forces were perceived as creating inequities. Implicit equity arguments emerged by how teachers defined success. Implications: Innovative design and practices used in alternative schools are insufficient for ensuring equity. Enactment of equity through pedagogical choices is reduced by policy procedures. Research is needed in areas: a) that will help teachers reflect on their values and priorities for at-risk students and b) of how efficacy is measured for the alternative school.
\end{abstract}

\section{Introduction}

Understanding the needs of students who are at risk to drop out of school is a near-essential element for educators when they formulate and design alternative educational settings. So essential, in fact, that it may be difficult for them to differentiate between at-risk student needs and educational equity. It has been established that successful alternative schools have critical design attributes that include the use of smaller class sizes, opportunity for self-paced instruction, crisis/behavioral intervention, remedial instruction, and accelerated instruction (Aron, 2006; Carver, Lewis, \& Tice (NCES), 2010; Raywid, 1994, 1999). Even though these design elements are widely adopted in practice, equity stemming from them is not always clear. In fact, we know that inequities are likely to be implicit in educational structures, offerings, or instructional practices (Yerrick \& Beatty-Adler, 2011). As a result of the implicit nature of inequity, teachers in these alternative schools, using what they consider innovative approaches, may not recognize inequity in their own practices. Therefore, in an attempt to advance beyond known and accepted program structures, this study examines teachers' enactment of equity in the alternative education settings.

Journal of Contemporary Issues in Education, 2011, 6(2), pp. 4-22

ISSN 1718-4770 @ 2011 University of Alberta

http://ejournals.library.ualberta.ca/index.php/JCIE 
Equity for the most part is complex and often measured in different ways. Some argue that equity discourse should include asking "whether learning outcomes are distributed randomly across race, ethnicity, and social class" (Jordan, 2010, p. 142). Others, such as policy makers, may place equity discourse in the context of law: that all students are afforded equal protection to receive an equitable education (e.g., No Child Left Behind [NCLB] Act of 2001); whereas Maleyco \& Gawlik (2011) suggest high-level achievement standards that are measurable for all students frame a necessary equity discourse. Regardless of which equity frame is used, much is left to human agency to ensure equity (Cohen, Moffitt, \& Goldin, 2007).

With the reliance on individuals, policy studies of any kind should include consideration of an individual's capacity and commitment to enact new practices (Spillane, 1999). Of particular interest in this study is the role of the teacher as an equity policy actor, who now must consider the intrinsic value of equity. More specifically, this study focuses on how alternative school teachers define, interpret, and enact equity for at-risk students.

By all accounts, teachers are expected to administer and comply with district, state, and federal policies and laws affecting schools. Implementing equity policies, such as NCLB, may simply be a part of the legal and political context in which teachers do their work (Gardiner, Canfield-Davis, \& Anderson, 2009). At the same time, teachers are being required to negotiate and put in place these policies amid diverse knowledge and skill bases (Cohen \& Ball, 1990; Darling-Hammond, 1990; Madsen, 1994; Shin, Gerard, \& Bowyer, 2010). Complicating matters for alternative school teachers is that they are under increasing pressure to create and sustain innovative strategies and practices to keep the struggling student engaged long enough to graduate from high school.

\section{Background}

One recent estimate suggests that a student in the United States drops out of high school every nine seconds (Hupfeld, 2010). These are very likely the same students who are members of ethnic minority groups, who experience academic failure and who live in poverty (Egemba \& Crawford, 2003; Griffin, 2002; Suh, Suh \& Houston, 2007). To compound the issues further, nearly half of the nation's African-American students and nearly 40 percent of Latino students attend high schools in which graduation is not the norm (Uribe, 2010). Therefore there is much to consider when planning an educational experience for an at-risk student population.

Students attending alternative education settings have traditionally not had success in regular public schools (Beken, Williams, Combs, \& Slate, 2010). Studies have shown that most of these students experience physical or emotional abuse, neglect, or abandonment; live under the poverty line; have fewer support systems; earn poor grades; and live in high-crime neighborhoods (Miller, 2004). Typically, they enroll in alternative schools because of poor grades, truancy, disruptive behavior, suspension, pregnancy, and other similar factors associated with an early departure from high school (Paglin \& Fager, 1997). In addition, these students are more likely than their peers at the traditional high school to have higher mobility, live in foster care or with a relative other than a parent, be dependent on alcohol or drugs, and experience violence and victimization (Ruiz de Velasco et al., 2008). These risk factors taken separately or together suggest that these students experience a great deal of turbulence in their lives, making them more vulnerable and susceptible to dropping out of school. For many, the alternative school setting provides an avenue for these students to remain in school.

Besides keeping students in school long enough to graduate, districts can use the alternative schools to improve the quality of education for at-risk students (Hoyle \& Collier, 
2006). While state policy in general gives districts latitude to develop alternative programs, it is often left to alternative school educators to provide meaningful learning experiences to the least successful students (Ruiz de Velasco et al., 2008). It is also well documented that teacher efficacy remains a powerful factor impacting student learning and achievement (DarlingHammond, 2004; Evans, 2009; Rice, 2010). Achieving desired learning outcomes in the alternative school settings is often dependent on specific instructional strategies chosen by the teachers. In choosing which instructional method (e.g. independent study, interactive instruction, and experiential learning) to use, the teachers must also consider the individual needs of and the risk factor carried by the student (Aron, 2006). But, with the advent of more stringent accountability models, there has been a push to change how teachers teach, what they should teach, and determining acceptable levels of student mastery (Spillane, 2008).

Initially, due largely to NCLB, states established standards and performance-based accountability mechanisms as an attempt "to ensure that all children have the opportunity to obtain a high-quality education and reach proficiency on challenging state academic standards and assessments" (NCLB, 2002; p. 13). On one hand proponent argue this accountability data can provide stakeholders with information to assist with the decision-making process for school improvement (Donaldson, Christie, \& Mark, 2009; Ryan \& Cousins, 2009). However, NCLB's focus on high-stakes testing has been decried by many as intractable measures of school standing that often ignore student readiness and contextual issues (Martin \& Brand, 2006; Musoba, 2011; Ravitch, 2010). These critics contend that despite the volumes of statistics produced these mostly one dimensional and uniform performance measures offer an incomplete picture of individual progress.

Hypothetically, the pervasive influence of accountability may be redefining how teachers approach providing meaningful learning experiences. In turn, how these teachers define, interpret, and enact equity through their teaching may be impacted. Therefore, the following questions guided this research: (a) How do alternative school teachers create meaning from equity discourse? (b) What assumptions do they hold for their students amidst national equity policy? (c) What goals do they set for their students?

\section{Theoretical Frames}

For this study, two theoretical frames were used to describe how teachers create meaning about equity in order to define, interpret, and enact equity in alternative school settings: equity principles (Espinoza, 2007) and policy implementation (Pressman \& Wildavsky, 1973); specifically, the role of the individual in the policy process (Cohen, Moffit, \& Goldin, 2007; Madsen, 1994; Pressman \& Wildavsky, 1973; Spillane, Reiser, \& Reimer, 2002). These frames are of particular significance to this study because they offer lenses in which to reveal how alternative school teachers respond to student risk factors and national equity policy, simultaneously. First, equity principles that include fairness and justice are described in this study because they can be applied to both the individual and group level (Espinoza, 2007). In turn, this frame allows for understanding how teachers may perceive whether "one social group is being benefited relative to another" (Weale, 1978, p. 28). Second, a policy implementation frame is presented to be able to draw comparisons between policy initiatives and individual actions (Cohen, Moffit, \& Goldin, 2007; Madsen, 1994; Pressman \& Wildavsky, 1973; Spillane, Reiser, \& Reimer, 2002). Together, these frames allow the researcher to synthesize how teachers create meaning from policy across the educational process. By using these two frames, the 
researcher can apply general conditions of a teacher's belief, attitude, and knowledge of equity for his/her at-risk student as it relates to policy.

\section{Equity Principles}

For the purpose of this study, the researcher considered Hossain and Zeitlyn's (2010) suggestion that equitable access to education is more than just equal opportunities, and that defining equity must include measures of fairness and justice (Corson, 2001). In addition, the researcher considered Groenke's (2010) position that "educational equity is about much more than individual achievement" (p. 84). Yet we see evidence that policy makers continue to emphasize individual achievement as an absolute necessity to compete in a global society. And as policy makers contend, the only way to ensure achievement by all students is through an accountability system that includes common standards and standardized testing (Hursh, 2005).

In equity scholarship, there is an argument that suggests an apparent relationship between accountability policies and the meaningfulness of the work educators do in their professional capacity. For instance, initially it was thought that state accountability policies would help to advance the United States towards equitable schooling (e.g., Diamond \& Spillane, 2004; Mazzeo, 2001); that through an accountability policy framework, schools could ensure that every student has access to achieve the same high standard of performance (Diamond \& Spillane, 2004; Mazzeo, 2001). However, because "equity" arguments are normally used in a context relative to perceived social group benefits (Weale, 1978), using only accountability models to define equitable outcomes is not enough. Reducing equity discourse to strict accountability procedures may actually overshadow what teachers understand about equity. According to Rorrer, Skrla, and Scheurich (2008), it is most essential that equity is portrayed in an open and direct way in order to leave no doubts as to its intended meaning. However, far too often teachers do not have a clear understanding of inequity, or for that matter equity itself, in their own schools and districts (Groenke, 2010). Therefore, central to this study, the researcher places equity front and center by first exploring what educators believe about equity and in turn what they consider to be effective action plans in their practice to educate at-risk students.

Additionally, by applying equity principles (Espinoza, 2007) in this study, the researcher recognizes that outcomes for at-risk students enrolled in alternative education must have the same meaning, the same construct for students not considered at risk to dropping out of school. Because it is often left to school personnel to act as equity policy interpreters, in this role it is also expected that they analyze data in an authentic and consistent manner. Problems arise, though, when equity for the at-risk student is reconfigured by these policy actors.

Take, for example, Ruiz de Velasco et al.'s (2008) work with continuation schools (an alternative education setting) in California. They examined how schools and programs have functioned and responded to at-risk students since the onset of the accountability era. In response to concerns of what school and district leaders believed were enabling and constraining factors when working with students enrolled in an alternative school setting, the school leaders acknowledged that they "operate within a weaker school accountability system that contains fewer incentives for promoting student success than the accountability system applied to comprehensive schools" (Ruiz de Velasco et al., 2008, p. 6). School leaders from that study also commented that they were challenged to be more innovative in their practice (staffing and instruction) in order to successfully meet accountability standards and performance requirements. 
However, innovations alone do not guarantee that equity is achieved. Using a critical theory frame, Kim and Taylor (2008) explored whether alternative schools/programs are beneficial to students in terms of equity. They found that principals wield considerable agency and authority in terms of program design. And with this power, these policy actors may perpetuate a cycle of academic inequality for the marginalized groups by focusing on innovative strategies that offer core basic courses, credit recovery, or accelerated credit versus putting forth a rigorous curriculum. This is important when considering if desired outcomes for at-risk students and their peers at traditional schools are aligned with official equity policy. In other words, are these official outcomes explicit in having the same meaning and the same construct for students regardless of the educational setting?

\section{Policy Implementation}

The second theoretical frame, policy implementation, is presented to examine how teachers enact equity through an implementation process. While broad policy strokes defining equity are drafted by federal and state policy makers, it is left to local education agencies to decode policy text in context to how it relates to their community and pass it on to those charged with the implementation (Spillane, 2008). As further explained by Rorrer, Skrla, and Scheurich (2008), district leaders are responsible for shaping policy into "district-specific derivatives" that result in policy coherence between "external policies and [district] internal goals and strategies" (p. 323).

However, as Spillane (2008) suggests, local translation and adaptation of policy does not necessarily mean that teachers understand and buy into a set of substantive ideas, or for that matter act on them. In fact, by the time policy is received by teachers, the various layers of governance may account for varying degrees of interpretation (Spillane, 2002). Interpretation of policy is beyond simply knowing about policy; rather teachers, as policy actors, are challenged to construct meaning from policy that mandates specific outcomes (Smit, 2005). However, it may be more complicated for alternative school teachers to construct meaning from policy about equity.

According to Ball (1993), teachers, in general, first conceptualize policy based on their own history, experiences, skills, resources, and context. And then, they apply a subjective moral or ethical judgment that might bypass the letter of the law in the interest of the spirit of the law (Bronfenbrenner, 1973; Gans, 1973; Jones-Wilson, 1986; Konvitz, 1973). This may prove to be even more troublesome for teachers of at-risk students. Because people attach different meaning to concepts of fairness and justice (Harvey \& Klein, 1985), the alternative school teachers, in addition to contending with their own subjective realities that construct, filter, meditate, and shape their educational practice (Smit, 2005), may also be influenced by their students' experiences and histories concerning risk.

\section{Methodology}

This research was designed as a qualitative cross-case study focusing on a unit of similar groups of people within a specified phenomenon, event, or program based on certain characteristics (Merriam, 1998). Using a cross-case design (Yin, 2003) and a prior-researchdriven approach (Boyatzis,1998), the major themes of opportunity and equity arguments emerged from the analysis to explain how teachers define, interpret, and enact equity policy in 
alternative school settings. According to Yin (2003), using multiple case studies serves as a viable option when attempting to address questions that are not easily discernable. For the purpose of exploring equity discourse, including how an alternative school teacher responds to the intrinsic nature of equity, a qualitative approach at five schools was utilized.

This study first employed a qualitative thematic strategy of data analysis concerned with the equity discourse used by teachers in alternative school settings. This analysis process became the unit of coding wherein these participants' interviews became the unit of analysis. The qualitative thematic analysis (Morse \& Richards, 2002) was used to categorize and make judgments about the interpretation of the data. The researcher then applied Fairclough's (1989, 1992, 1995) three-dimensional framework of critical discourse analysis using (a) governmental artifacts, (b) discursive practices (interviews) involving the context of which statements and texts are framed and debated, and (c) social practices (observations) of the relation of discourse within a wider power of structure and ideology. This analytical procedure allowed important themes and categories to emerge inductively from the data across participants.

\section{Data Sources}

The School Context. Well before the federal call for educational equity, state policy makers in California and Texas had in place alternative education policy encouraging districts to create alternative schools that are a different design of schooling that focuses on the needs of atrisk students. The setting for this study was five district-supported academic alternative high schools: two in California and three in Texas. A stratified purposeful sampling strategy was utilized (Patton, 2001). First, these states were chosen because they continue to redefine policies that serve students who are at risk of dropping out of school as well as offer important similarities of student demographics. In choosing the participating districts, the following criteria was used: (a) the district must have responded to state legislative actions with local policy in the creation of a dropout prevention program; (b) student demographics of each district reflect a cross-section of diversity, to include social economic status, gender, and race; and (c) there was a sustainability (more than ten years of operation) of their alternative education school or program. Further, these district-supported schools emphasized a change in pedagogy and curriculum in order to meet the individual needs of students as opposed to alternative schools that focus primarily on punitive/disciplinary issues relating to student behavior and their treatment/rehabilitation of behavior. Additionally, effort was made to ensure diversity across school composition to include district/school size, student ethnicity, student social economic status, and special programs population (English language learners, migrant, and special education).

Table 1 summarizes the geographical, demographic and student enrollment context of the five participating schools in this study. 
Table 1: Demographic Characteristics of Participating Schools, Reported for 2006-2007
$\begin{array}{cccc}\text { Demographics* } & \text { Lakeview Fireside } & \text { Oak } & \text { Sunrise } \\ \text { Terrace } & \text { Academy } & \text { Learning } \\ \text { Center }\end{array}$
Elmhurst

Student

Enrollment

41

315

191

$\sim 125$

73

African

American

0

$1.6 \%$

0

$32 \%$

$15 \%$

Hispanic

$83 \%$

$35 \%$

$96 \%$

$22 \%$

$38 \%$

White

$15 \%$

$58 \%$

$4 \%$

$26 \%$

$43 \%$

Economically

Disadvantaged

$70 \%$

$28 \%$

$89 \%$

$31 \%$

$4 \%$

English

Language

Learners

$49 \%$

$9 \%$

$5 \%$

$11 \%$

Special

Education

$6 \%$

$10 \%$

$8 \%$

$9 \%$

$1 \%$

Title 1

No

No

Yes

No

No

*All school names are pseudonyms.

\#Data reflect district demographics.

Two of the schools had a large Hispanic population (83\% and $96 \%$ ) with most students economically disadvantaged (70\% and $89 \%$, respectively). Two of the other schools had semiequal differentiated demographics among African American, Hispanic, and White populations. All schools shared a similar mission to serve a student population identified as predominantly at risk for school failure, by their respective state policy.

Teacher Participants. Interviews were conducted with 15 teachers. Critical variation occurred across gender, ethnicity, and experience (see Table 2.). 
Table 2: Demographic Outline of Participating Teachers

\begin{tabular}{|c|c|c|c|c|c|}
\hline $\begin{array}{l}\text { Teacher } \\
\text { Names* }\end{array}$ & School & Ethnicity & Gender & $\begin{array}{l}\text { Total Teaching } \\
\text { Experience/Yrs at } \\
\text { Current School }\end{array}$ & Role \\
\hline Leticia & Lakeview & Hispanic & $\mathrm{F}$ & $>15 / 1$ & ELA \\
\hline Elliot & Lakeview & Other & M & $>15$ years/ 1 & Math \\
\hline Robin & Lakeview & White & $\mathrm{F}$ & $<2$ years $/ 1$ & Sci/SS \\
\hline Sara & Fireside & White & $\mathrm{F}$ & $23 / 8$ & ELA \\
\hline Steve & Fireside & White & M & $25 / 25$ & Science \\
\hline Robert & Fireside & White & M & $18 / 18$ & Math \\
\hline Barbara & Fireside & White & $\mathrm{F}$ & $30 / 18$ & Social Studies \\
\hline Linda & Fireside & White & $\mathrm{F}$ & $30 / 26$ & Special Education \\
\hline Monica & Fireside & Hispanic & $\mathrm{F}$ & $>15 />15$ & Parenting \\
\hline Cam & $\begin{array}{l}\text { Oak } \\
\text { Terrace }\end{array}$ & White & $\mathrm{F}$ & $11 / 6$ & Science \\
\hline Cathy & $\begin{array}{l}\text { Sunrise } \\
\text { Academy }\end{array}$ & White & $\mathrm{F}$ & $7 / 3$ & ELA \\
\hline Venetia & $\begin{array}{l}\text { Sunrise } \\
\text { Academy }\end{array}$ & $\begin{array}{c}\text { African } \\
\text { American }\end{array}$ & $\mathrm{F}$ & $3 / 3$ & Science \\
\hline Roger & $\begin{array}{l}\text { Sunrise } \\
\text { Academy }\end{array}$ & $\begin{array}{c}\text { African } \\
\text { American }\end{array}$ & M & $20 / 15$ & Math \\
\hline Kameria & $\begin{array}{l}\text { Sunrise } \\
\text { Academy }\end{array}$ & Other & $\mathrm{F}$ & $5 / 5$ & Science \\
\hline Holly & $\begin{array}{l}\text { Elmhurst } \\
\text { L.C. }\end{array}$ & White & $\mathrm{F}$ & $15 / 12$ & Social Studies \\
\hline
\end{tabular}

*All names are pseudonyms.

Of the 15 teachers who participated, 11 were female and four were male, two were African American, two Hispanic, nine White, and the ethnicities of the remaining two teachers self- 
identified as Other. The teaching experiences and courses taught by these participants varied. The majority of the teachers had both traditional and alternative school experiences, with one teacher having taught in a home school setting prior. Furthermore, variation across what courses these teachers taught included the four core content areas of math, science, social studies, and English as well as teachers who taught special education content mastery and parenting were included in the study.

\section{Data Collection}

Data collected included (a) governmental artifacts of state policies addressing at-risk students, district policy pertaining to dropout prevention/recovery, state/federal accountability measures for alternative education, campus/district accountability documents, student academic progress templates, school brochures, school websites, and newsletters/ newspaper articles; (b) school observations consisting of various scenarios of administrator/teacher/student interaction (office, classroom, before school, after school, transition periods, community meetings), faculty meetings, and when available school/community socials; and (c) interviews conducted with 15 teachers at five alternative schools of choice.

Observations were performed and recorded using scripting and writing down anecdotal comments and behaviors in various contexts and interactions (Merriam, 1998). Site visits occurred over the course of an academic year. In all schools, the purpose of these observations was to document evidence relating to the practice of administrating equity policy.

Teacher interviews took place on their campus during normal school hours. Interview protocols focused on open-ended question relating to circumstances of employment, measurements used by teachers to define student success, and discussion of teachers' approaches/responses to implementing their states' accountability policy. Pre- and postinterviews were conducted with teachers concerning specific instances of practice and artifacts that were observed and collected.

\section{Data Analysis}

A discourse analysis process became the unit of coding wherein the participants' interviews became the primary unit of analysis. Policy text and observations became the secondary unit. The interviews were analyzed in a number of phases. A discursive logic following Kenway (1990), Taylor, Rizvi, Lingard, and Henry (1997), and Gale (1999) mapped the interconnectedness between policy as text—the "what"; policy as ideology—the "why"; and policy as discourse - the "how." By utilizing a discourse analysis methodology, assumptions and motivations of judgments of equity expressed by teachers working at alternative schools were revealed. This method is appropriate to studying how educators construct and eventually enact meaning from equity policy.

A prior-research-driven approach was used to identify critical discourse themes (Boyatzis, 1998) and compared data from this study with the policy implementation literature. The interview data were compiled on a coding spreadsheet, and a content analysis of identifying the frequency of themes was conducted. In order to ensure a reliability of judgment by the researcher, several safeguards were implemented. These safeguards included consideration of diverse perspectives when examining teachers' comments and maintaining sensitivity to themes with the data interpretation (Boyatzis, 1998). 


\section{Findings}

For this study, the researcher followed a discursive logic (Gale, 1999; Kenway, 1990; Taylor, Rizvi, Lingard, \& Henry, 1997) to map the interconnectedness between policy as text and policy in action. First, when available, national and state policies relating to equity are presented, followed by how teachers interpreted and administered these policies in context to equity discourse. The findings are then presented as representations issued by the teachers' interviews and action.

Consistent with Corson's (2001) theorizing that equity includes fairness and justice, the researcher equally applied policy literature to explain the role of the teacher as a policy actor (Ball, 1993; Bronfenbrenner, 1973; Gans, 1973; Konvitz, 1973; Jones-Wilson, 1986; Smit, 2005). The main themes and subthemes (as indicated in parentheses) that emerged from the data are presented under the following headings and subheadings in parenthesis: opportunity (entitlement) and equity arguments (implicit).

Opportunity

A recurring theme in equity policy studies has to do with the ways in which policy makers make explicit that they conceptualize equity as opportunity (Espinoza, 2007). From the federal policy of No Child Left Behind Act of 2001 (NCLB), policy makers expect that all children have an opportunity (emphasis added) to obtain a high-quality education as well as reach proficiency on state assessments. Yet, Corson (2001) reminds us that equity must also consider fairness and justice as a provision in education. It is less clear in this policy how fairness and justice are measured. Taken in a broader sense, justice may well be an action associated in accordance with the requirement of some law. On one hand, then, it appears that justice for the at-risk student may be linked to state legislative efforts. For example, California and Texas authenticate the alternative schools as a natural solution and fair opportunity for atrisk students to remain in school to obtain a high school diploma through their educational policies (Texas Education Code, TEC \$29.081(d), TEA, 2007a; California Education Code, CEC $44865,46170,48400-48438$, and 51055, CDE, n.d.-a).

These states recognize that not all students are successful in the traditional comprehensive high school. For these students, there is a need for an alternative education environment that uses nontraditional structure, strategies, and accountability standards. In this sense, it appears that fairness is achieved because particular attention is paid to the proper interest and needs of the students. Without the alternative school, moreover, a student not successful in a traditional high school is likely to drop out.

Teachers' Response. In four of the cases, the teachers were confident that the alternative school was the only means of opportunity for their students to graduate from school. For instance, at Sunrise Academy, Venetia, a science teacher who was relatively new to the career field, shared, "Oh my goodness, I wish there were opportunities like this for us when we were in high school, because some people just don't do well in a traditional setting." Cam, a science teacher from Oak Terrace, shared that many of her students were enrolled because "for whatever reason, there's some issue or some obstacle that they've had that's kept them from making all the connections; and they have some big gaps." She went on to say, "If they could finish in 4 years, then why would they need to be here?"

As suggested by Espinoza (2007), "On the face of it, equity would seem only requires that access [to any public school, including alternative] be extended to as many as possible, and perhaps to all" (p. 349). Yet, creating fair and just opportunities (as defined by legislative 
actions) for at-risk students to enroll in alternative school settings is not without potential inequitable consequences, specifically with regard to distribution of resources. For instance, alternative schools across the nation have experienced increased enrollment in the last decade (Carver, Lewis, \& Tice, 2010); to the point that districts cap their enrollment because there is not enough space or teachers to handle the ever-increasing influx of students. Interesting enough, for four schools participating in this study, as indicated from their school accountability reports, across-the-board enrollment increases, over a five year period, were negligible. However, many of the teachers across all cases shared that it is not unusual for their students to be placed on waiting lists before being allowed to enroll.

According to teachers, enrollment in these schools spiked the beginning of every school year and every grading period thereafter. For example, at Elmhurst Learning Center, Holly shared that at the beginning of the school year, her school gets a large group of new students, "because we try to pack them in, you know and then some of our kids will be graduating in the first 6 weeks. So we keep a steady stream of kids coming in." At Elmhurst, this process was repeated every 6 weeks. Similar stories of compacted and spiked enrollment were shared across all cases.

Districts may interpret this cyclic enrollment as a way to meet the "timely" needs of atrisk students who may be on the verge of failing courses at their home campus. For many of these students enrollment at the alternative school is the only opportunity for them to remain in school and recover credits lost to failing grades. Although this research did not specifically investigate district motives it was clear from the teachers' interviews that cyclic enrollment was expected and accepted.

Entitlement. A subtheme of entitlement emerged from the data in that not all teachers accepted the equity principle of "fairness of distribution" (Espinoza, 2007, p. 349); to include as many at-risk students as possible in their school. More specifically, based on the data, it appears that the teachers used their beliefs, attitudes, and knowledge of student history to grant or deny access to their classroom and to instruction. For instance, according to Sara, the English Language Arts teacher at Fireside, "students are more likely to be 'helped' when they follow the rules and have built a relationship with the teacher." She continues: "If they need my class because this is where they work and this is where they've got a relationship, I'm fine; but I just don't take anyone."

This scenario of gate keeping and entitlement was further substantiated by other teachers at other schools as well. If progress in either behavior or academics (i.e., course completion) could not be documented, then the student was referred back to his/her home campus. In many cases, teachers commented that it was not unusual in these cases the student often would not show up at his/her home campus and in turn become one of many dropouts in the district.

\section{Equity Arguments}

The second major theme to emerge was equity arguments. Weale (1978) places equity arguments in context of "when one social group is being benefited relative to another" (p. 28). Several teachers believed that students enrolled at traditional high schools were benefited relative to their own students. Take, for example, Barbara's experience in a district social studies curriculum meeting. According to her, district leaders make explicit their concern for the students enrolled in Advanced Placement (AP) courses. These are the same students who are preparing to attend college. These are also the students who attend traditional high schools. Barbara remarked that the district wanted to mandate a geography class for all ninth graders, but specifically for AP students. At the time, the degree plan for a high school diploma (in the 
district) did not require any social studies course for ninth graders. But district leaders felt that students enrolled in AP courses needed a geography course to help them prepare for college. Originally, the course was to be offered as an elective; but because a neighboring district mandated it across its district, Barbara's district wanted to follow suit. At least to a point; she went on to explain that for her ninth-grade students enrolled at Fireside, they would not be required to take geography. Rather, they could take an extra course, like English, whether they needed it or not. According to Barbara, she tried to reason with the district curriculum directors that this action would further set back her students.

At which point I said, "So what you are doing is you are setting them up to have two giant steps behind all the other kids. They are already one step behind because they have gaps and holes way more than most kids, and now they will have even less knowledge in history."

Implicit equity arguments. While explicit equity arguments arose in several interviews, implicit equity arguments were more common amongst the participants and in fact occurred across all cases. From the interviews, it appeared the teachers relied on what they considered to be a morally correct, feasible and intellectually defensible course of action (Rein \& Rabinovitz, 1978) to educate their at-risk students as opposed to following state and district mandated policy expectations concerning core curriculum. Teachers shared that many of their students overcome personal, social, and academic obstacles and from these stories the teachers then created measurements to define student success.

To begin, both the interview and observational data suggest that the teachers recognized that each student has a special interest or extraordinary ability that requires a different teaching and learning approach. More importantly, these teachers made clear that they rarely used state standards to define success for their students. For Cathy, she measured student success by whatever was accomplished by the students; with success based on individual circumstance and need. For instance, one student was successful by writing a complete sentence, while another student was deemed successful by completing a six-page research paper. She contended that "you can't measure it all in grades, you measure it in personal growth; you measure it in how they treat people." Holly used a similar measurement, "If I have a kid that sits still for a day and actually reads and writes a little bit, and that is progress over the day before and weeks before, that's measurement. But I don't put a number on it."

For the participating teachers, they parlayed showing up to school, not doing drugs, following the rules, completing so many credits in a given timeframe as the more important goals for their students to achieve. Day after day, these measures of success became indiscriminate and accepted as the norm for the at-risk student. As illustrated below with Lakeview's accountability data (and similar to the other participating schools), an outcome of these expectations is that there was no assurance that the students were provided with a set of academic skills.

When examining the percentage of students who tested proficient at Lakeview, the school accountability report card (2006-2007) reflected that when data were available, the majority minority (Hispanic) and children of poverty subgroups did not score at either the proficient or advanced level for English language art, math, and history.

\section{Discussion of Findings}

To answer the three questions posed in this study-(a) how do alternative school teachers create meaning from equity discourse? (b) what assumptions do they hold for their students amidst national equity policy? and (c) what goals do they set for their students? - this researcher 
used equity principles and policy implementation literature as theoretical frames to examine how teachers in alternative school settings define, interpret, and enact equity.

How do alternative school teachers create meaning from equity discourse?

In many cases, as the data suggest, by the time an equity policy is received by teachers, there is little to counter a narrow interpretation that opportunity equates to equity. This finding is consistent with other equity studies (e.g., Espinoza, 2007). Interestingly enough, alternative school teachers in this study first drew constructs of student risk factors. Then they applied equity to mean these students having an opportunity to enroll in their school, and last, that students are able to acquire credit quickly. But once the students enrolled, there were limited educational opportunities beyond typical alternative school instructional designs that included computer-based programs, self-paced programs, and accelerated curriculum. In addition, district and teacher decisions further limited a student's opportunity for acquiring a high quality education as intended by NCLB. In fact, district decisions may exclude at-risk students enrolled in alternative school settings from a common, more rigorous curriculum. The teachers also used exclusionary activities themselves; they served as gate keepers to their classrooms, and often excluded instructional practices that would challenge students to reach their fullest potential. In practical terms, the data from this study are consistent with Groenke's (2010) supposition that teachers lack knowledge about inequity and equity. The data also suggest that teachers can differentiate explicit examples of inequities if the actions resulting in inequities are committed by other people. From the data, though, it appears that teachers had a more difficult time with implicit equity arguments in that they do not see their own actions as leading to inequities.

What assumptions do alternative school teachers hold for their students amidst national equity policy?

As stated earlier, the assumption was that NCLB would set in motion teacher effort to improve student learning. However, the question now arises as to how these efforts translate into teachers enacting educational equity for at-risk students. The evidence presented illustrates that equity in educational attainment prompted by policy intent is not easily discernable by teachers in these alternative schools. For instance, it appeared that teachers didn't place value to bring forward federal and state accountability when measuring student performance and outcomes. This resulted in inconsistent measures of performance and outcomes. According to Espinoza (2007), unequal performances may result in unequal rewards for their students. This in turn may result in social and political issues. The data offered that while individual differences can and were analyzed by the teachers, academic achievement (as intended by NCLB) was not a primary consideration for these teachers. In fact, many of the teachers readily admitted that their students struggled and often did not pass state assessments. With this outcome, these students may actually strengthen group identities of academic failure. Thus, by virtue of teachers' beliefs and knowledge of what they consider best for their students, these teachers may actually negate any progress intended by policy to move towards equity for an at-risk student population.

What goals do alternative school teachers set for their students?

It is difficult to attribute teacher actions observed and described in interviews as intentional actions to create inequities. From the data, teachers used measurements of success that were dependent on the type of risk factor the students carried. The risks associated with these students were dependent first on how students were defined as being at risk of dropping out of school (i.e., academic low success), as being at-risk of harm to self (i.e., drugs) or others (i.e., disciplinary); and in which all are discursively constituted. And as such, because "risks" are socially constructed, expectations may change based on the norms, morals, and beliefs at work in 
a given society at a given time (Lupton, 1999). For these students, possibilities of success ranged from personal to social to academic. But, again, these measures did not necessarily guarantee that students received a quality education. A concern arises that education policy may eventually legitimize the current ideologies and practices of the educators in these specialized schools.

As alternative schools continue to secure their place in the educational system, traditional boundaries and current accountability practices are poised to challenge a system that now includes a large number of at-risk students requiring individual support and encouragement and perhaps different measures of success. What is disconcerting is there continues to exist little consensus defining academic and student achievement standards that accurately reflect educational equity for at-risk students (Kim \& Taylor, 2008).

\section{Conclusion}

This research yields important implications for practitioners, policy makers, and researchers. This study revealed that innovative designs and practices currently used by practitioners, and supported by policy, are insufficient for ensuring that at-risk students are afforded educational equity. It appears that teachers still exercise individual options to engage students in ways that they feel best suit the students' needs. There is also evidence to suggest that they are guided in part by procedures outlined in the state education policy code. However, these procedures may constrain their pedagogical choices. Based on the data, it is reasonable to expect alternative school teachers to currently organize and strategize their instructional strategies based on their knowledge of a student's social, personal, and academic needs and in the context of the high prevalence that at-risk students do drop out of school. The results from this study suggest that a teacher's choice of how that teacher approaches risk is an important determinant of how that faculty member decides his/her instructional strategies, and sets goals.

These data continue to point to the separation between professed values of equity and actual practice. One might be tempted to conclude that the scope of equity, as interpreted by these teachers, relates strictly to concepts of opportunities and access; but that is unlikely to be the case in every situation. These participants had various levels of experience across states, districts, and types of schools, which may influence how they respond to policy implementation. It is not the intent of the author to represent this group of educators as one undifferentiated group, all having similar relationships with at-risk students. The researcher is aware of the complexity that exists when teaching in alternative schools. These schools, and the educators who work in them, are challenged on many fronts to provide services for the at-risk student. This researcher's responsibility was to represent alternative school teachers in a manner that captured their experiences as teachers of at-risk students.

Another important implication of these findings is that the focus of future research on alternative schools, at-risk students, and equity should include two key perspectives: First, further research might consider the use of a participatory pathways analysis to help teachers reflect on their values and priorities to build capacity to move towards academic rigor and to merge innovation and accountability. The researcher believes additional research needs to be conducted to disaggregate these participants' experiences. These studies will further define the opportunities or obstacles at-risk students encounter because of how educators administer policy.

Second, although previous research on alternative schools has focused almost exclusively on student characteristics, and program design and structures; further research should also pay close attention to the efficacy of these schools. Instead of focusing only on the 
innovativeness of these schools, it is important to collect data on core student outcomes that include student retention, student achievement, and attendance and dropout rates. In fact, to date, no research has included measuring causal impact of these schools as an indicator of equity. 


\section{References}

Aron, L. Y. (2006). An overview of alternative education. Washington, DC: The Urban Institute. Retrieved August 1, 2008, from http://www.urban.org/UploadedPDF/411283_alternative_education.pdf

Ball, S. J. (1993). What is policy? Texts, trajectories and toolboxes. Discourse, 13(2), 10-17.

Beken, J., Williams, J., Combs, J., \& Slate, J. (2010). Academic alternative school settings: A conceptual analysis, part 1. International Journal of Educational Leadership Preparation, 5(2). Retrieved May 1, 2011, from http://cnx.org/content/m34134/1.1/

Boyatzis, R. E. (1998). Transforming qualitative information: Thematic analysis \& code development. Thousand Oaks, CA: Sage Publications.

Bronfenbrenner, M. (1973, September). Equality and equity. Annals, 409, 5-25.

California Department of Education (CDE). (n.d.-a). Alternative schools of choice: Program summary. Retrieved March 1, 2008, from http://www.cde.ca.gov/sp/eo/as/asprogramsummary.asp

Carver, P. R., Lewis, L. \& Tice, P. (2010). Alternative Schools and Programs for Public School Students at Risk of Educational Failure (NCES 2007-08). Washington, DC: National Center for Education Statistics. Retrieved December 1, 2010, from http://nces.ed.gov/pubsearch/pubsinfo.asp?pubid=2010026

Cohen, D. K., \& Ball, D. L. (1990). Policy and practice: An overview. Educational Evaluation and Policy Analysis, 12(3), 223-239.

Cohen, D. K., Moffitt, S. L., \& Goldin, S. (2007). Policy and practice: The dilemma. American Journal of Education, 113(8), 515-548.

Corson, D. (2001) Ontario students as a means to a government's ends. Our Schools/Our Selves, $10(4), 55-77$.

Darling-Hammond, L. (1990). Teaching and knowledge: Policy issues posed by alternative certification for teachers. Peabody Journal of Education, 67(3), 123-154.

Darling-Hammond, L. (2004). Inequality and the right to learn: Access to qualified teachers in Californian public schools. Teachers College Record, 106(10). 1936-1966.

Diamond, J. B., \& Spillane, J. P. (2004). High-stakes accountability in urban elementary schools: Challenging or reproducing inequality? Teachers College Record, 106, 11451176.

Donaldson, D. I., Christie, C. A., \& Mark, M. M. (2009). What counts as credible evidence in applied research and evaluation practice? Los Angeles, CA: Sage Publications.

Egemba, M. O., \& Crawford, J. R. (2003). An analysis of Hispanic students/drop out rates. Paper presented at the annual meeting of the American Educational Research Association, Chicago. Retrieved June 5, 2008, from http://www.eric.ed.gov/ERICDocs/data/ericdocs2sql/content_storage_01/0000019b/80/1 b/23/f6.pdf.

Espinoza, O. (2007). Solving the equity-equality conceptual dilemma: A new model for analysis of the educational process. Educational Research, 49(4), 343-363.

Evans, A. (2009). No child left behind and the quest for educational equity: The role of teachers' collective sense of efficacy. Leadership and policy in schools, 8(1), 64-91.

Fairclough, N. (1989). Language and power. London, England: Longman.

Fairclough, N. (1992). Discourse and social change. Cambridge, England: Polity Press.

Fairclough, N. (1995). Critical discourse analysis. London, England: Longman.

Gale, T. (1999). Trajectories: Treading the discursive path of policy analysis. Discourse: 
Studies in the Cultural Politics of Education, 20(3), 393-407.

Gans, H. J. (1973). More equality. New York, NY: Pantheon.

Gardiner, M. E., Canfield-Davis, K., \& Anderson, K. L. (2009). Urban school principals and the "No child left behind" act. Urban Review, 41, 141-160.

Griffin, B. W. (2002). Academic misidentification, race, and high school dropouts. The High School Journal, 85(4), 71-81.

Groenke, S. L. (2010). Seeing, inquiring, witnessing: Using the equity audit in practitioner inquiry to rethink inequity in public schools. English Education, 4(1), 83-96.

Harvey, G. \& Klein, S. (1985). Understanding and measuring equity in education: A conceptual Model. Journal of Educational Equity and Leadership, 5(2), 145-168.

Hossain, A., \& Zeitlyn, B. (2010, December). Poverty, equity and access to education in Bangladesh. Create Pathways to Access. Research monograph No. 51.

Hoyle, J. R., \& Collier, V. (2006). Urban CEO superintendents' alternative strategies in reducing school dropouts. Education and Urban Society, 39(1), 69-90.

Hupfeld, K. (2010). A review of the literature: Resiliency skills and dropout prevention. Scholar Centric. Denver CO. Retrieved June 1, 2011 from http://www.scholarcentric.com/images/pdf/resiliency_skills/SC_Resiliency_WP_ FNL.pdf

Hursh, D. (2005). Neo-liberalism, markets and accountability: Transforming education and undermining democracy in the United States and England. Policy Futures in Education, 3(1), 3-15.

Jones-Wilson, F. C. (1986). Equity in education: Low priority in the school reform movement. Urban Review, 18(1), 31-39.

Jordan, W. (2010). Defining equity: Multiple perspectives to analyzing the performance of diverse learners. Review of Research in Education, 34, 142-178. doi: 10.3102/0091732X09352898

Kenway, J. (1990). Gender and education policy: A call for new directions. Geelong, Australia: Deakin University Press.

Kim, J-H, \& Taylor, K. A. (2008). Rethinking alternative education to break the cycle of educational inequality and inequity. Journal of Educational Research, 101(4), 207-219.

Konvitz, M. R. (1973). Equity in law and ethics. In P. Wiener (Ed.), Dictionary of the history of ideas: Studies of selected pivotal ideas, Vol. 2 (pp. 148-154). New York, NY: Charles Scribner's Sons. .

Lupton, D. (1999). Crime control, citizenship and the state: Lay understandings of crime, its causes and solutions. Journal of Sociology, 35(3), 297-311.

Madsen, J. (1994). Educational reform at the state level: The politics and problems of implementation. Washington, DC: The Falmer Press, Education Policy Perspective Series

Maleyko, G. \& Gawlik, M.A. (2011). No child left behind: What we know and what we need to know. Education, 131(3), 600-624.

Mazzeo, C. (2001). Frameworks of state: Assessment policy in historical perspective. Teachers College Record, 103, 367-397.

Merriam, S. B. (1998). Qualitative research and case study applications in education. San Francisco, CA: Jossey-Bass.

Miller, R. (2004). A brief history of alternative education. Retrieved September 30, 2010, from http://www.educationrevolution.org/history.html 
Morse, J. M., \& Richards, L. (2002). Readme first for a user's guide to qualitative methods. Thousand Oaks, CA: Sage.

Musoba, G. D. (2011). Accountability policies and readiness for college for diverse students. Educational Policy, 25(3), 451-487.

No Child Left Behind (NCLB). (2002). A desktop reference. Retrieved March 15, 2008, from http://www.ed.gov/admins/lead/account/nclbreference/reference.pdf

Paglin, C., \& Fager, J. (1997). Alternative schools: Approaches for students at risk. Portland, OR: Northwest Regional Educational Laboratory. Retrieved May 15, 2008, from http://www.nwrel.org/request/sept97/.

Patton, M. Q. (2001). Qualitative research \& evaluation methods. ( $3^{\text {rd }}$ ed.). Thousand Oaks, CA: Sage.

Pressman, J. L., \& Wildavsky, A. (1973). Implementation. Berkley, CA: University of California Press.

Ravitch, D. (2010). The death and life of the great American school system: How testing and choice are undermining education. New York, NY: Basic Books.

Raywid, M. A. (1994). Alternative schools: The state of the art. Educational Leadership, 52(1), 26-31.

Raywid, M. A. (1999, May). History and issues of alternative schools. The Education Digest, pp. 47-51.

Rein, M., \& Rabinovitz, R. (1978). Implementation: A theoretical perspective. In W. D. Burnham \& M. W. Weinberg (Eds.), American politics and public policy (pp. 307-335). Cambridge, MA: M.I.T. Press.

Rice, S. M. (2010). Getting our best teachers into disadvantaged schools: Differences in the professional and personal factors attracting more effective and less effective teachers to a school. Educational Research for Policy and Practice, 9(3), 177-192.

Rorrer, A., Skrla, L., \& Scheurich, J. (2008). Districts as institutional actors in educational reform. Educational Administration Quarterly, 44(3), 307-358.

Ruiz de Velasco, J., Austin, G., Dixon, D., Johnson, J., McLaughlin, M., \& Perez, L. (2008). Alternative Education Options: A Descriptive Study of California Continuation High Schools. An Issue Brief from the California Alternative Education Research Project (CAERP). Retrieved September 30, 2008, from: http://jgc.stanford.edu/docs/AEO\%20Issue\%20Brief\%204-26-08fin.pdf

Ryan, K. E., \& Cousins, J. B. Eds. (2009). Introduction, ix-xv, In K.E. Ryan and J. B. Cousins (Eds.), The sage international handbook of educational evaluation. Los Angeles, CA: Sage Publications.

Shin, J., Gerard, L., \& Bowyer, J. (2010). Getting from here to there: The roles of policymakers and principals in increasing science teacher quality. Journal of Science Teacher Education, 21, 283-307. doi: 10.1007/s10972-009-9180-5

Smit, B. (2005). Teachers, local knowledge, and policy implementation: A qualitative policypractice inquiry. Education and Urban Society, 37(3), 292-306.

Spillane, J. (1999). External reform initiatives and teachers' efforts to reconstruct their practice: The mediating role of teachers' zones of enactment. Journal of Curriculum Studies, 31(2), 143-175.

Spillane, J. (2002). Local theories of teacher change: The pedagogy of district policies and programs. Teachers College Record, 104(3), 377-420. 
Spillane, J. P. (2008). Policy, politics, and the national mathematics advisory panel report: Topology, functions, and limits. Educational Researcher, 37(9), 638-644.

Spillane, J. P., Reiser, B. J., \& Reimer, T. (2002). Policy implementation and cognition: Reframing and refocusing implementation research. Review of Educational Research, 72(3), 387-431.

Suh, S., Suh, J., \& Houston, I. (2007). Predictors of categorical at-risk high school dropouts. Journal of Counseling \& Development, 85(2), 196-203.

Taylor, S., Rizvi, F., Lingard, B., \& Henry, M. (1997). Educational policy and the politics of change. London, England: Routledge.

Texas Education Agency (TEA). (2007a). Alternative Education Accountability (AEA). Retrieved March 15, 2009, from http://www.ritter.tea.state.tx.us/aea/2007/index.html

Uribe, P. E. (2010). Early college high schools: Design principles and practices. Design Principles \& Practices: An International Journal, 4(2), 195-203.

Weale, A. (1978). Equality and social policy. London, England: Routledge \& Kegan Paul.

Yerrick, R., \& Beatty-Adler, D. (2011). Addressing equity and diversity with teachers through informal science institutions and teacher professional development. Journal of Science Teacher Education 22, 229-253. doi:10.1007/s10972-011-9226-3

Yin, R. K. (2003). Case study research: Design and methods. Thousand Oaks, CA: Sage. 